\title{
ОСОБЛИВОСТІ ФУНКЦІОНАЛЬНОГО СТАНУ ОРГАНІЗМУ ОСІБ ЮНАЦЬКОГО ВІКУ З РІЗНИМ РЕЗЕРВОМ ПРАЦЕЗДАТНОСТІ СЕРЦЯ
}

\author{
๑О. С. Волошин ${ }^{1}$, Г. Б. Гуменюк', М. В. Волошин ${ }^{2}$, Ю. С. Сморщок², Н. Г. Зіньковська \\ ${ }^{1}$ Тернопільський національний педагогічний університет імені Володимира Гнатюка \\ ${ }^{2}$ Тернопільський національний медичний університет імені І. Я. Горбачевського МОз України \\ ${ }^{3}$ Кременецька обласна гуманітарно-педагогічна академія імені Тараса Шевченка
}

PЕЗюМЕ. Функціональний стан організму значною мірою визначається характером та ефективністю механізмів його адаптації. Дослідження функціональних можливостей серцево-судинної системи дозволяє отримати широкий масив інформації про реактивність організму у відповідь на коливання умов середовища.

Мета - дослідити особливості показників діяльності серцево-судинної системи, рівень адаптаційного потенціалу, рівень тренованості апарату зовнішнього дихання, толерантність до розумових навантажень з метою оцінки функціонального стану організму осіб із різним рівнем працездатності серця.

Матеріал і методи. В ході роботи обстежено 60 практично здорових осіб юнацького віку. Вивчали показники частоти серцевих скорочень, артеріального тиску, адаптаційного потенціалу за Баєвським, резервні можливості системи дихання за Скібінським і рівень тренованості апарату зовнішнього дихання за Розенталем, досліджували індекс Робінсона, а також показники толерантності до розумового навантаження.

Результати. В обстежених із рівнем індексу Руф'є вище середнього (1-а група) 88,9 \% осіб має задовільний рівень адаптаційного потенціалу, тоді як в осіб із середнім рівнем індексу Руф'є (2-а група) задовільний рівень адаптаційних реакцій мали лише 60,0 \% обстежених.

В осі6 1-ої групи резервні можливості системи дихання мають кращі показники: у 22,3 \% осіб встановлено добрий рівень індексу Скібінського, 66,7 \% обстежених мали задовільний рівень цього показника. Водночас в осіб 2-ої групи добрий рівень індексу Скібінського мали 10 \% обстежених, 80 \% осіб - задовільний, ще 10 \% - низький рівень. Серед обстежених 1-ї групи домінують особи з високим рівнем толерантності до розумового навантаження - $60 \%$.

Висновки. У групі з вищими показниками функціональних резервів серця на 20,8 \% більше осіб із задовільним рівнем адаптаційного потенціалу, на 12,3 \% більше обстежених із добрим рівнем індексу Скібінського. Особи з більшим резервом працездатності серця демонструють кращі показники толерантності до розумового навантаження.

КлючовІ СлОВА: функціональний стан; індекс Руф'є; адаптаційний потенціал; індекс Скібінського; проба Розенталя.

Вступ. Функціональний стан організму значною мірою визначається характером та ефективністю механізмів його адаптації. Фізіологічним проявом адаптаційного потенціалу $\epsilon$ належна якість перебігу пристосувальних реакцій організму без порушення рівноваги між діяльністю серця і гемодинамічними показниками. Адаптаційний потенціал системи кровообігу вважають відображенням співвідношення рівня функціонування, ступеня напруги регуляторних механізмів домінуючої системи і функціонального резерву [1].

Дослідження функціональних можливостей серцево-судинної системи дозволяє отримати широкий масив інформації про реактивність організму у відповідь на коливання умов середовища. Важливе значення у сучасній фізіології має кількісне вираження функціональної характеристики серцево-судинної системи [2]. Дослідження показують значну кореляційну залежність адаптаційного потенціалу серцево-судинної системи з показниками діяльності серця, меншою $є$ кореляція 3 масою тіла [3].

Діапазон пристосувальних можливостей організму та механізми їх реалізації тісно пов'язані 3 рівнем соматичного здоров'я. Вагоме значення в цьому сенсі мають дослідження загальної адаптованості до фізичних навантажень і рівень аеро6ної здатності організму. Функціональні показники серцево-судинної і дихальної систем визначають фізіологічну характеристику індивідуального здоров'я людини [4].

Особливо вагоме значення має оцінка функціонального стану організму, адаптаційного потенціалу і рівня соматичного здоров'я осіб юнацького віку [5-8]. Особи цієї вікової категорії формуються за умов зниженої динамічної активності, гіпокінезії, порушення звичних добових ритмів, значного інформаційного навантаження [9]. Зазначене впливає на функціональний стан серцево-судинної системи, що особливо проявляється після навантажень, зокрема у вигляді шлуночкової екстрасистолії [10]. Важливість досліджень зазначеної спрямованості визначає також факт негативної динаміки показників стану здоров'я молоді в Україні $[7,8]$.

Слід зазначити, що функціональний стан організму і ефективність адаптаційних реакцій істотно залежать від домінуючого контуру регуляції. Автономна нервова система однією з перших реагує на 
Огляди літератури, оригінальні дослідження, погляд на проблему, випадок з практики, короткі повідомлення зміни погодних умов і визначає початок формування адаптаційних реакцій організму [11]. Розширення діапазонупристосувальних реакцій, спрямованих на підтримання оптимального рівня функціонального стану організму, має особливе значення за сучасних умов істотних змін клімату, що вимагає відповідних реакцій регуляторних систем, кардіореспіраторної системи, фізичного розвитку організму і соматичного здоров'я в цілому [12].

Мета - дослідити особливості показників діяльності серцево-судинної системи, рівень адаптаційного потенціалу, рівень тренованості апарату зовнішнього дихання, толерантність до розумових навантажень для оцінки функціонального стану організму й адаптаційних можливостей осіб із різним рівнем працездатності серця.

Матеріал і методи дослідження. Робота $\epsilon$ фрагментом комплексного дослідження функціонального стану організму осіб юнацького вікового періоду. В ході роботи було обстежено 60 практично здорових осіб віком 19-21 рік у період з 9 до 11 години. За рівнем функціональних резервів серця обстежених поділили на осіб із рівнем індексу Руф'є вище середнього (1-а група) і середнім рівнем (2-а група) [13]. 3 метою дослідження особливостей функціонального стану організму в осіб із різним рівнем працездатності серця вивчали показники частоти серцевих скорочень, систолічного і діастолічного артеріального тиску, досліджували показники адаптаційного потенціалу за Баєвським [13], резервні можливості системи дихання за Скібінським і рівень тренованості апарату зовнішнього дихання за Розенталем $[13,14]$, досліджували індекс Робінсона, а також показники толерантності до розумового навантаження в осіб юнацького віку $[13,15]$. При рівні довірчої вірогідності 0,95 (p<0,05) визначали довірчий коефіцієнт t i порівнювали його із значенням за таблицею Стьюдента при даній кількості спостережень [16]. 3 метою кореляційного аналізу отриманих даних досліджували коефіцієнт кореляції Пірсона [17]. Статистичну обробку отриманого цифрового матеріалу проводили з використанням статистичного пакета STATISTICA 6.1. та пакета програм Microsoft Excel 2014.

Результати й обговорення. У 30,76 \% обстежених індекс Руф'є (IP) мав значення вище середнього (1-а група), у 69,23 \% осіб - середній рівень (2-а група). Значення частоти серцевих скорочень (ЧСС) були в межах норми, хоча в обстежених другої групи показник виявився вищим, відповідно $(77,56 \pm 2,92)$ і $(82,20 \pm 3,02)$ уд./хв. Значення систолічного артеріального тиску становило $(115,11 \pm$ $1,64)$ мм рт. ст. в осіб 1-ої групи і $(111,0 \pm 3,14)$ мм рт. ст. - в осіб 2-ої групи. Показник діастолічного артеріального тиску суттєво не відрізнявся в обох

групах і склав відповідно $(71,44 \pm 2,81)$ і $(71,50 \pm$ $2,99)$ мм рт. ст. $(p<0,05)$.

Функціональний стан організму (ФСО) істотно залежить від успішності роботи регуляторних систем, зокрема, гуморальної і автономної нервової. Вказані контури регуляції активно впливають на синусний вузол провідної системи серця, що пояснює тісний зв'язок між успішністю роботи серцево-судинної системи, ФСО і якістю пристосувальних реакцій. Серед усього контингенту обстежених показник адаптаційного потенціалу за Баєвським мав задовільний рівень у 73,68 \% осіб, у 15,78 \% відзначено напруження механізмів адаптації, в 10,52 \% - незадовільний рівень адаптації. Серед осіб з рівнем IP вище середнього 88,9 \% осіб мають задовільний рівень адаптаційного потенціалу і лише у 11,1 \% спостерігали напруження механізмів адаптації. У другій групі задовільний рівень адаптаційних реакцій мали 60,0 \% обстежених, 20 \% осіб - напруження пристосувальних механізмів і ще у 20 \% відзначено незадовільний рівень адаптації $(p<0,05)$ (рис. 1).

В осі6 з IP вище середнього резервні можливості системи дихання та їі стійкість до кисневого голодування мають кращі показники: 22,3 \% становили особи із добрим рівнем індексу Скібінського, 66,7 \% обстежених мали задовільний рівень цього показника, а 11,0 \% осіб - незадовільний рівень. Серед осіб з середнім рівнем IP лише у $10 \%$ відзначено добрий, у 80 \% - задовільний, ще у $10 \%$ - незадовільний рівень показника індексу Скібінського ( $<<0,05)$ (рис. 2).

Аналіз рівня тренованості апарату зовнішнього дихання за допомогою проби Розенталя показав наступне. У 44,5 \% осіб із значенням IP вище середнього спостерігали незначне зростання показників життєвої ємності легень (ЖЄЛ) протягом 5 проб, у групі з середнім рівнем функціональних резервів серця частка таких осіб склала 30,0 \%. У решти обстежених обох груп показники жєЛ під час проби суттєво не змінювались. Негативної динаміки проби Розенталя в обох групах, незалежно від рівня функціональних резервів серця, не спостерігали.

За результатами аналізу показник індексу маси тіла в осіб із рівнем серцевої працездатності вище середнього становить $(20,5 \pm 4,23)$ кг/м², що відповідає нормі. В обстежених із середнім рівнем індексу Руф'є цей показник склав $(26,25 \pm 2,52)$ кг/м², що на 3,25 перевищує показник норми і на 2,88 більше середнього значення усього контингенту обстежених ( $p>0,05)$.

Значення індексу Робінсона (індексу подвійного добутку у спокої) характеризує критерії резерву та економізації функцій серцево-судинної системи. В усього контингенту обстежених цей 
Огляди літератури, оригінальні дослідження, погляд на проблему, випадок з практики, короткі повідомлення

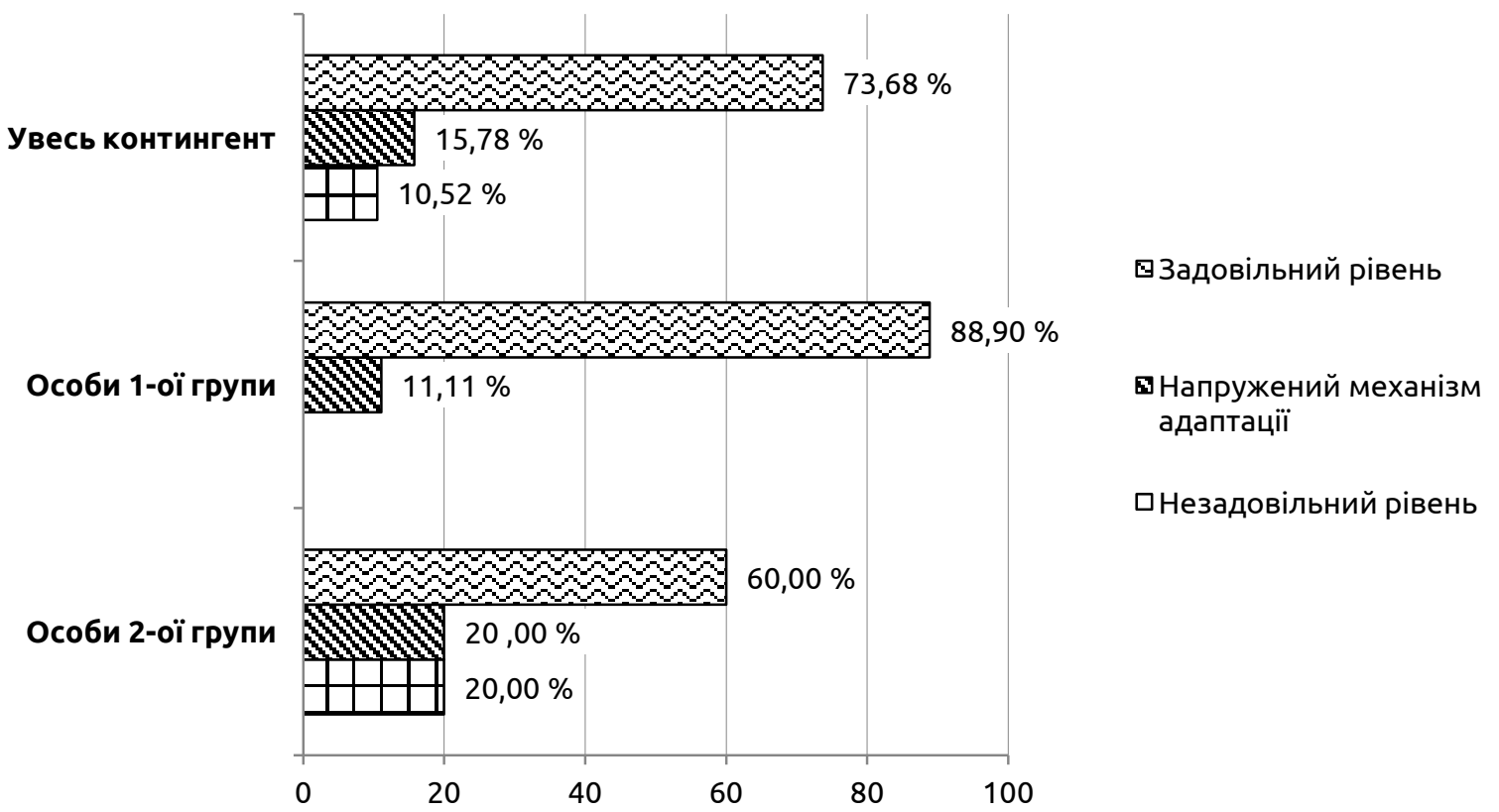

Рис. 1. Показники адаптаційного потенціалу в осіб із різним резервом працездатності серця (кількість oci6 y \%).

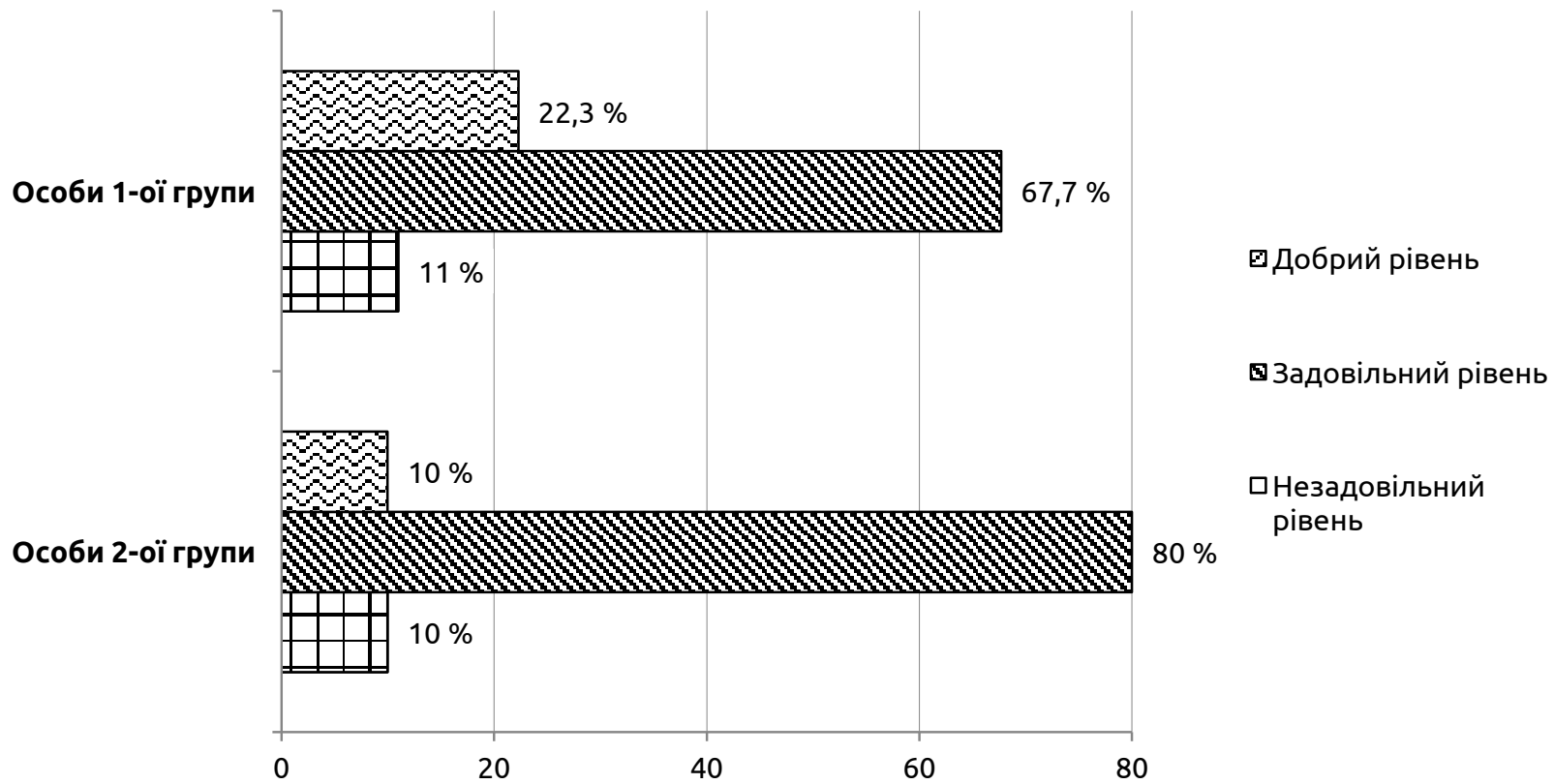

Рис. 2. Показники функціональних можливостей системи дихання за Скібінським в осіб із різним резервом працездатності серця (кількість осіб у \%).

показник систолічної роботи серця склав $(79,53 \pm$ 3,02). В осіб 1-ої групи індекс Робінсона відповідає значенню вище середнього істановить $76,40 \pm 3,15$, а в обстежених 2-ої групи - 82,66 33,96 (середній рівень індексу Робінсона) ( $<<0,05)$.

Дослідження толерантності нервової системи до розумового навантаження дозволило встановити таке: 16,66 \% осіб мають високий рівень толерантності до розумового навантаження,
$50,0 \%$ - збережений рівень, 22,23 \% - помірно знижений, а 11,10 \% - знижений рівень толерантності $(p>0,05)$.

У групі з рівнем серцевої працездатності вище середнього $60 \%$ осіб мають високий рівень толерантності до розумового навантаження, у 20 \% встановлено збережений рівень толерантності і ще у $20 \%$ - помірно знижений рівень. У групі з середнім рівнем функціональних резервів 
Огляди літератури, оригінальні дослідження, погляд на проблему, випадок з практики, короткі повідомлення серця 61,53 \% обстежених мають збережений рівень толерантності до розумового навантаження, у 23,07 \% встановлено помірно знижену толерантність, ще 15,38 \% осіб мали знижений рівень толерантності. Середнє значення лабільності нервової системи перед розумовим навантаженням в осіб 1-ої групи становило 204,2ะ7,64, у дру-

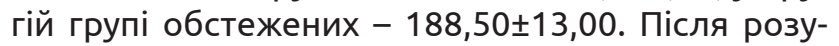
мового навантаження ці показники склали відпо-

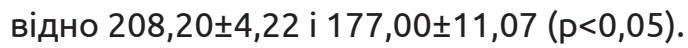

Використання коефіцієнта кореляції Пірсона дозволило встановити позитивний кореляційний зв'язок між індексом Робінсона і показниками лабільності нервової системи до та після розумового навантаження. Позитивний кореляційний зв'язок встановлено між показниками обстежених як 1-ої, так і 2-ої груп, однак високого рівня кореляція відсутня. При цьому найбільше значення кореляційного зв'язку - 0,55 - відзначено між показником індексу Робінсона і лабільністю нервової системи перед розумовим навантаженням в осіб із рівнем працездатності серця вище середнього.

Висновки. 1. За умов спокою показники систолічного і діастолічного артеріального тиску, а також частоти серцевих скорочень, відповідають нормі в обстежених обох груп, хоча в осіб 2-ої групи середнє значення чСС вище на 4,64 уд./хв. Ступінь механічного навантаження на стінки судин обстежених зберігається у фізіологічних межах, як в

\section{ЛІТЕРАТУРА}

1. Вернигородський В. С. Оцінка реабілітаційного потенціалу і реабілітаційний прогноз у хворих на гіпотиреоз / В. С. Вернигородський, Н. М. Фетісова, М. В. Вернигородська // Вісник проблем біології і медицини. 2018. - Вип. 1, Т. 2 (143). - С. 100-103.

2. Показники кінцевого діастолічного і систолічного об'ємів лівого шлуночка, ударного і хвилинного об'єму серця, фракції викиду та ударного й серцевого індексів у здорових чоловіків і жінок Поділля за даними електрокардіографії / О. В. Власенко, І. В. Гунас, Р. О. Шеремета, І. Л. Рокунець // Вісник Вінницького національного медичного університету. - 2014. - № 2, Т. 18. - С. 461-465.

3. Оцінка адаптаційного потенціалу серцево-судинної системи студентів I курсу / Т. Г. Дерека, В. М. Туманова, І. І. Бистра, О. В. Гацко // Journal «ScienceRise: Pedagogical Education». - 2017. - № 10 (18). - C. 13-17.

4. Воскобойнікова Г. Л. Концепція комплексної оцінки адаптаційних можливостей у формуванні і збереженні індивідуального здоров'я людини / Г. Л. Воскобойнікова // Наука і освіта. - 2014. - №8. - С. 35-39.

5. Волошин О.С. Оцінка стану соматичного здоров'я осіб юнацького віку з різним рівнем функціонального резерву серця / О. С. Волошин, Г. Б. Гуменюк // Вісник наукових досліджень. - 2019. - № 1. - С. 28-33.

осіб з індексом Руф'є вище середнього, так і з середнім рівнем індексу.

2. Отримані дані свідчать про потенційно кращий функціональний стан організму осіб із вищим резервом працездатності серця. Серед обстежених із вищими показниками функціональних резервів серця на 20,8 \% більше осіб із задовільним рівнем адаптаційного потенціалу, на 12,3 \% більше обстежених із добрим рівнем індексу Скібінського, на 14,6 \% більше осіб з незначною позитивною динамікою проби Розенталя, що свідчить про вищий рівень резервних можливостей і тренованість апарату зовнішнього дихання $(p<0,05)$.

3. Особи з більшим резервом працездатності серця демонструють кращі показники толерантності до розумового навантаження, що свідчить про адекватний рівень лабільності нервової системи і сили нервових процесів в осіб цієї групи. Рухливість нервових процесів в осіб 1-ої групи після розумового навантаження підвищилась на 4,0, тоді як в осіб 2-ої групи - зменшилась на 11,5 (р<0,05).

Перспективи подальших досліджень. Вивчення особливостей функціонального стану організму осіб юнацького віку є фрагментом комплексного дослідження. Отримані дані можуть бути спрямовані на оптимізацію навчального процесу із врахуванням функціональних резервів кардіореспіраторної системи і функціонального стану осіб цього вікового періоду.

6. Леонтьєва Зоряна. Розрахунок адаптаційного потенціалу, оцінка адаптаційних можливостей організму і рівнів здоров'я студентів Львівського національного медичного університету імені Данила Галицького / Зоряна Леонтьєва // Праці НТШ. Медичні науки. Оригінальні дослідження: клінічні науки. - 2017. - T XLVII. C. 64-70.

7. Козак Д. В. Щоденна рухова активність - запорука міцного здоров'я під час навчання студентів спеціальності «Здоров' я» / Д. В. Козак, В. Б. Коваль, В. В. Шафранський // Вісник соціальної гігієни та організації охорони здоров'я України. - 2015. - № 2 (64) . - С. 28-31.

8. Гербут К. В. Оцінка фізичного стану старшокласників міста Чернівці / К. В. Гербут, В. Г. Хоменко // Young Scientist. - 2015. - № 4 (19) . - C. 67-72.

9. Волошин О. С. Оцінка характеру психомоторної активності та фізичного розвитку організму осіб юнацького віку / О. С. Волошин, Г. Б. Гуменюк // Вісник наукових досліджень. - 2017. - № 4. - С. 77-79.

10. Іванов І. В. Оцінка рівня функціонального стану серцево-судинної системи у студенток 1-4 курсів спеціалізації «Фітнес» / І. В. Іванов, Л. А. Рубан, М. О. Бурмакіна // Наука і освіта. - 2014. - №4. - С. 64-68.

11. Вадзюк С. Н. Вплив вестибулярного навантаження на систему кровообігу за різних типів погоди / 
Огляди літератури, оригінальні дослідження, погляд на проблему, випадок з практики, короткі повідомлення С. Н. Вадзюк, Р. М. Шмата, Л. Б. Лозіна // Art of Medicine. 2019. - № 4 (12). - С. 36-43.

12. Денефіль О. В. Аналіз серцево-судинної захворюваності населення м. Тернополя залежно від впливу показників атмосферного тиску / О. В. Денефіль, В. Р. Снітинський // Вісник соціальної гігієни та організації охорони здоров'я України. - 2014. - Т. 2. - С. 97-101.

13. Зінченко В. Б. Фізичне виховання. Методи самоконтролю фізичного стану: практикум для студентів усіх напрямів підготовки / В. Б. Зінченко, В. В. Білецька, Л. В. Ясько. - К. : НАУ, 2015. - 48 с.

14. Марчик В. Л. Функціональні проби та індекси в дослідженні фізичного стану людини: методичні рекомендації / В. Л. Марчик, І. І. Мінжоріна. - Кривий Ріг : КПІ ДВНЗ «КНУ», 2016. - 64 с

\section{REFERENCES}

1. Vernyhorodskyi, V.S., Fetisova, N.M., \& Vernyhorodska, M.V. (2018). Otsinka reabilitatsiinoho potentsialu i reabilitatsiynyi prohnoz u khvorykh na hipotyreoz [Estimation of rehabilitation potential and rehabilitation prognosis in patients with hypothyroidism]. Visnyk problem biolohii $i$ medytsyny - Bulletin of Problems of Biology and Medicine, 1/2 (143), 100-103 [in Ukrainian].

2. Vlasenko, O.V., Hunas, I.V., Sheremeta, R.O., \& Rokunets, I.L. (2014). Pokaznyky kintsevoho diastolichnoho i systolichnoho obiemiv livoho shlunochka, udarnoho i khvylynnoho obiemu sertsia, fraktsii vykydu ta udarnoho y sertsevoho indeksiv u zdorovykh cholovikiv i zhinok Podillia za danymy elektrokardiohrafii [Indicators of end-diastolic and systolic volumes of the left ventricle, stroke and cardiac output, ejection fraction and stroke and heart indices in healthy men and women of Podillya according to electrocardiography]. Visnyk Vinnytskoho natsionalnoho medychnoho universytetu - Bulletin of Vinnytsia National Medical University, 2 (18), 461-465 [in Ukrainian].

3. Dereka, T.H., Tumanova, V.M., Bystra, I.I., \& Hatsko, O.V. (2017). Otsinka adaptatsiinoho potentsialu sertsevo-sudynnoi systemy studentiv I kursu [Evaluation of the adaptive potential of the cardiovascular system of first-year students]. Journal "ScienceRise: Pedagogical Education", 10 (18), 13-17 [in Ukrainian].

4. Voskoboynikova, H.L. (2014). Kontseptsiia kompleksnoi otsinky adaptatsiinykh mozhlyvostei u formuvanni i zberezhenni indyvidualnoho zdorovia liudyny [The concept of a comprehensive assessment of adaptive capabilities in the formation and preservation of individual human health]. Nauka i osvita - Science and Education, 8, 35-39 [in Ukrainian].

5. Voloshyn, O.S., \& Humenyuk, H.B. (2019). Otsinka stanu somatychnoho zdorovia osib yunatskoho viku z riznym rivnem funktsionalnoho rezervu sertsia [Estimation of somatic health of adolescents with different levels of functional reserve of the heart]. Visnyk naukovykh doslidzhen Bulletin of Scientific Research, 1, 28-33 [in Ukrainian].

6. Leontyeva, Z. (2017). Rozrakhunok adaptatsiinoho potentsialu, otsinka adaptatsiinykh mozhlyvostei orhanizmu i rivniv zdorovia studentiv Lvivskoho natsionalnoho medychnoho universytetu imeni Danyla Halytskoho [Calculation of adaptive potential, assessment of adaptive

capabilities of the body and levels of health of students of Lviv National Medical University named after Danylo Halytskyi]. Pratsi NTSH. Medychni nauky. Oryhinalni doslidzhennia: klinichni nauky - Proceedings of NTSh. Medical sciences. Original research: Clinical Sciences, 47, 64-70 [in Ukrainian].

7. Kozak, D.V., Koval, V.B., Shafranskyi, V.V. (2015). Shchodenna rukhova aktyvnist-zaporuka mitsnoho zdorovia pid chas navchannia studentiv spetsialnosti "Zdorovia" [Daily physical activity - the key to good health during the training of students majoring in "Health"]. Visnyk sotsialnoi hihiieny ta orhanizatsii okhorony zdorovia Ukrainy - Bulletin of Social Hygiene and Health Care Organizations of Ukraine, 2 (64), 28-31 [in Ukrainian].

8. Herbut, K.V., \& Khomenko, V.H. (2015). Otsinka fizychnoho stanu starshoklasnykiv mista Chernivtsi [Assessment of the physical condition of high school students in Chernivtsi]. Young Scientist, 4 (19), 67-72 [in Ukrainian].

9. Voloshyn, O.S., Humenyuk, H.B. (2017). Otsinka kharakteru psykhomotornoi aktyvnosti ta fizychnoho rozvytku orhanizmu osib yunatskoho viku [Estimation of the nature of psychomotor activity and physical development of the body of young people]. Visnyk naukovykh doslidzhen - Bulletin of Scientific Research, 4, 77-79 [in Ukrainian].

10. Ivanov, I.V., Ruban, L.A., \& Burmakina, M.O. (2014). Otsinka rivnia funktsionalnoho stanu sertsevo-sudynnoi systemy u studentok 1-4 kursiv spetsializatsii "Fitnes" [Estimation of the level of functional state of the cardiovascular system in students of 1-4 years of study in Fitness specialization]. Nauka i osvita - Science and Education, 4, 64-68 [in Ukrainian].

11. Vadzyuk, S.N., Shmata, R.M., \& Lozina, L.B. (2019). Vplyv vestybuliarnoho navantazhennia na systemu krovoobihu za riznykh typiv pohody [Influence of vestibular load on the circulatory system in different types of weather]. Art of Medicine, 4 (12), 36-43 [in Ukrainian].

12. Denefil, O.V., Snitynskyi, V.R. (2014). Analiz sertsevo-sudynnoi zakhvoriuvanosti naselennia m. Ternopolia zalezhno vid vplyvu pokaznykiv atmosfernoho tysku [Analysis of cardiovascular morbidity of the population of Ternopil depending on the influence of atmospheric pressure indicators]. Visnyk sotsialnoi hihiieny ta orhanizatsii okhoro- 
Огляди літератури, оригінальні дослідження, погляд на проблему, випадок з практики, короткі повідомлення ny zdorovia Ukrainy - Bulletin of Social Hygiene and Health Care Organization of Ukraine, 2, 97-101 [in Ukrainian].

13. Zinchenko, V.B., Biletska, V.V., \& Yasko, L.V. (2015). Fizychne vykhovannia. Metody samokontroliu fizychnoho stanu: praktykum dlia studentiv usikh napriamiv pidhotovky [Physical education. Methods of self-control of a physical condition: practicum for students of all directions of preparation]. Kyiv: NAU [in Ukrainian].

14. Marchyk, V.L., \& Minzhorina, I.I. (2016). Funktsionalni proby ta indeksy $v$ doslidzhenni fizychnoho stanu liudyny: metodychni rekomendatsii [Functional tests and indices in the study of the physical condition of man: guidelines]. Kryvyi Rih: KPI DVNZ "KNU" [in Ukrainian].

15. Okhromiy, H.V., Dzyuba, O.M., Makarova, N.Y., \& Nozdrin, S.V. (2014). Ekspres-diahnostyka tolerantnosti do navantazhen u studentiv vyshchykh uchbovykh zakladiv:

metodychni rekomendatsii [Express-diagnostics of tolerance to loadings at students of higher educational institutions: methodical recommendations]. Kyiv: State Institution "UISD of the Ministry of Health of Ukraine", Dnipropetrovsk: "UDKHTU" [in Ukrainian].

16. Shelamova, M.A., Insarova, N.I., \& Leshchenko, V.G. (2010). Statisticheskiy analiz mediko-biologicheskikh dannykh s ispolzovaniyem programmy YeXEL: uchebno-metodicheskoye posobiye [Statistical analysis of biomedical data using the EXEL program: a teaching tool]. Minsk: BSMU [in Russian].

17. Yeroshkina, T.V. (Ed.). (2014). Metodychni vkazivky do praktychnykh zaniat iz dystsypliny "Medychna statystyka" [Methodical instructions for practical classes in the discipline "Medical Statistics"]. Dnipropetrovsk: Lira [in Ukrainian].

\section{ОСОБЕННОСТИ ФУНКЦИОНАЛЬНОГО СОСТОЯНИЯ ОРГАНИЗМА ЛИЦ ЮНОШЕСКОГО ВОЗРАСТА 3 РАЗНЫМ РЕЗЕРВОМ ТРУДОСПОСОБНОСТИ СЕРДЦА}

\section{○Е. С. Волошин ${ }^{1}$, Г. Б. Гуменюк', М. В. Волошин ${ }^{2}$, Ю. С. Сморщок' , Н. Г. Зинковская ${ }^{3}$}

${ }^{1}$ Тернопольский национальный педагогический университет имени Владимира Гнатюка

${ }^{2}$ Тернопольский национальный медицинский университет имени И. Я. Горбачевского МОз Украины

${ }^{3}$ Кременецкая областная гуманитарно-педагогическая академия имени Тараса Шевченко

PЕЗЮМЕ. Функциональное состояние организма в значительной степени определяется характером и эффективностью механизмов его адаптации. Исследование функциональных возможностей сердечно-сосудистой системы позволяет получить широкий массив информации о реактивности организма в ответ на колебания условий среды.

Цель - исследовать особенности показателей деятельности сердечно-сосудистой системы, уровень адаптационного потенциала, уровень тренированности аппарата внешнего дыхания, толерантность К умственным нагрузкам для оценки функционального состояния организма лиц с различным уровнем работоспособности сердца.

Материал и методы. В ходе работы обследовано 60 практически здоровых лиц юношеского возраста. Изучали показатели частоты сердечных сокращений, артериального давления, адаптационного потенциала по Баевскому, резервные возможности дыхательной системы по Скибинскому и уровень тренированности аппарата внешнего дыхания по Розенталю, исследовали индекс Робинсона, а также показатели толерантности к умственной нагрузке.

Результаты. У обследованных с уровнем индекса Руфье выше среднего (1-я группа) 88,9 \% лиц имеют удовлетворительный уровень адаптационного потенциала, тогда как у лиц со средним уровнем индекса Руфье (2-я группа) удовлетворительный уровень адаптационных реакций имели только 60,0% обследованных.

У лиц 1-ой группы резервные возможности дыхательной системы имеют лучшие показатели: хороший уровень индекса Скибинского установлен у 22,3 \% лиц, 66,7 \% обследованных имели удовлетворительный уровень этого показателя. В то же время у лиц 2-ой группы хороший уровень индекса Скибинского имели $10 \%$ обследованных, 80 \% лиц - удовлетворительный, еще 10 \% - низкий уровень. Среди обследованных первой группы доминируют лица с высоким уровнем толерантности к умственной нагрузке - $60 \%$.

Выводы. В группе с высокими показателями функциональных резервов сердца на 20,8 \% больше лиц с удовлетворительным уровнем адаптационного потенциала, на 12,3 \% больше обследованных с хорошим уровнем индекса Скибинского. Лица с высшим резервом работоспособности сердца демонстрируют лучшие показатели толерантности к умственной нагрузке.

КЛЮЧЕВЫЕ СЛОВА: функциональное состояние; индекс Руфье; адаптационный потенциал; индекс Скибинского; проба Розенталя. 
Огляди літератури, оригінальні дослідження, погляд на проблему, випадок з практики, короткі повідомлення

FEATURES OF FUNCTIONAL CONDITION OF THE BODY OF YOUNG PERSONS WITH DIFFERENT RESERVE OF HEART DISABILITY

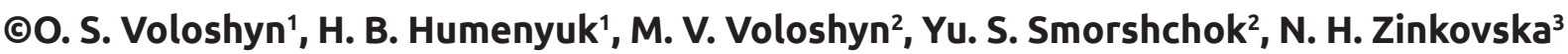 \\ ${ }^{1}$ Ternopil Volodymyr Hnatiuk National Pedagogical University \\ ${ }^{1}$ I. Horbachevsky Ternopil National Medical University \\ ${ }^{1}$ Kremenets Taras Shevchenko Regional Humanitarian-Pedagogical Academy
}

SUMMARY. The functional state of the body is largely determined by nature and effectiveness of mechanisms of its adaptation. The study of functional capabilities of cardiovascular system allows to get a wide array of information about the reactivity of body in response to fluctuations in environment.

The aim - to study activity of cardiovascular system, adaptive potential, training of breathing apparatus, tolerance to mental load.

Material and Methods. 60 practically healthy young persons were examined. The indicators of heart rate, blood pressure, Baevsky adaptive potential, Skibinsky index indicators, Rosenthal tests, Robinson index and mental load tolerance were studied.

Results. $88.9 \%$ of young people had a satisfactory level of adaptive capacity in group with Ruffier index is above average. Only $60.0 \%$ of the examined had a satisfactory level of adaptive capacity in group with average level of the Rufier index.

The respiratory system has better performance in group 1: the good level of Skibinsky index was set in $22.3 \%$ of people, and $66.7 \%$ had a satisfactory level of this index. At the same time, $10 \%$ of the surveyed had a good level of Skibinsky index in group 2, 80 \% of them had the satisfactory index, and another $10 \%$ had a low level of Skibinsky index. The persons with high level of tolerance to mental load dominate in group 1 and formed $60 \%$.

Conclusions. There are more people with satisfactory level of adaptive potential in $20.8 \%, 12.3 \%$ more people with a good level of Skibinsky index in the group with high rates of functional reserves of the heart. Persons with large reserve of heart performance demonstrate the best indicators of tolerance to mental load.

KEY WORDS: functional status; Ruffier index; adaptive potential; Skibinsky index; Rosenthal test.

Отримано 20.05.2020 